\title{
Impact of Capital Flight on Tax Revenue in Nigeria: A Co-integration Approach
}

\author{
Damilola Felix Eluyela ${ }^{1}$, Inemesit Bassey ${ }^{2}$, Olufemi Adebayo Oladipo ${ }^{1}$, Adekunle Emmanuel Adegboyegun ${ }^{1}$, \\ Abimbola Ademola ${ }^{1} \&$ Joseph Madugba \\ ${ }^{1}$ Department of Accounting and Finance, Landmark University, Omu Aran, Kwara State, Nigeria \\ ${ }^{2}$ Department of Accounting, Covenant University, Ota, Ogun State, Nigeria \\ Correspondence: Damilola Felix Eluyela, Department of Accounting and Finance, Landmark University, Omu Aran, \\ Kwara State, Nigeria. E-mail: eluyela.damilola@lmu.edu.ng
}

Received: February 6, 2020

doi:10.5430/rwe.v11n5p141
Accepted: March 30, 2020

Online Published: September 3, 2020

URL: https://doi.org/10.5430/rwe.v11n5p141

\begin{abstract}
This study presents an empirical analysis of the impact of capital flight on tax revenue in Nigeria. We made use of secondary data collected from the Central Bank of Nigeria Statistical Bulletin of various issues, Federal Inland Revenue Services and National Bureau of Statistics. The empirical measurement covers the sample period between 1980 and 2015. An Ordinary Least Square, Augmented Dickey-Fuller unit root test, Error Correction Mechanism and Co-integration test was adopted in the study. The results revealed that the Gross Domestic Product has a significant effect in the positive direction, while capital flight and inflation rate have a significant effect in the negative direction. The study recommended that the Federal Inland Revenue System, the department saddled with the responsibility of tax collection, should review the tax system and policies with the aim of plugging loopholes in the existing tax system thereby preventing organizations from evading and avoiding taxes.
\end{abstract}

Keywords: tax revenue, capital flight, gross domestic product, inflation rate

JEL Classification: H2, M41, O1

\section{Introduction}

For decades, the movement of illicit funds from African countries and developing countries in general to the developed economies has been the bane of the economic development of these nations. The effect of this has been the low level of development in these countries, and more often than not, these funds carted away to evade the tax authorities in the originating country thereby reducing their tax-generating abilities; the host nations' ability to raise capital to finance its capital projects is diminished because they do not have full tax revenues and their economic plans are unnecessarily altered and delayed. Cash outflow without taxation has various economic, socio-political and developmental consequences. This has a severe militating impact on the development prospects of many developing countries, leading to the erosion of their tax base and inevitably their ability to invest in infrastructure upon which broad-based economic growth depends; difficulty in public financial budgeting as actual tax revenue is less than expected tax revenue and the provision of essential basic public services such as education and healthcare. Subsequently, Isu (2002) explains the plethora of challenges that surround the issue of capital flight, particularly its negatives effects on the economic condition of a nation. He went further to assert that the extreme nature of capital flight is that it reduces the resources available to these countries and impede their ability to address the collective problems and developmental issues of the country. According to Pastor (1990) and Kapoor (2008), the flights of capital not only shrink a country's tax base by shifting wealth and resources beyond the reach of the government but also make taxes less progressive.

Capital flight is defined in various ways because different scholars see it in different lights and used it in different studies. Still, its existence is mostly associated with three key reasons - investment, money laundering, and tax evasion (De Boyrie, 2010). Isu (2002) sees it as all private capital outflows from developing countries, whether short-term or long-term. One of the motives of capital flight is to avoid taxation on wealth, including that which may have been acquired illegally. Similarly, tax revenue is regarded as the revenue generated by the government of a nation through the imposition of taxes on individuals and corporate organizations (Libabatu, 2014). This source of 
government income helps in stimulating the economic performance of a country and also helps the government to meet the basic social needs of good roads, electricity, health facilities and so on.

In general, capital flight is seen in a negative light virtually in many research works since its inception in the 1970s (De Boyrie, 2010; Ugwuanyi \& Uguru 2010; Olugbenga \& Alamu 2013), it is related to corruption, bribery or theft committed by government leaders and their officials. As a matter of fact, its impacts on macroeconomic variables of the affected countries, mostly developing countries, Nigeria inclusive have been mostly negative. These negative consequences are generally seen by the different school of thoughts to include; worsening fiscal balance, increase in debt burden, budget deficit and reduced private sector investment (Boyce \& Ndikumana, 2009; Olugbenga \& Alamu, 2013); falling external reserves (Lessard \& Williamson, 1987); reduction in a country's tax base (Ajadi, 2008); slow economic growth, rising inflation and acute inability to compete globally (Onwioduokit, 2007; Menbere, 2003). It is purely a criminal activity perpetrated by multinational companies using different means to transfer their profits abroad and so avoid paying taxes on them (Uguru, 2016).

The negative impacts of capital flight are many and broad in the sense that it affects the entire economic activities of the host nations, mostly developing countries. In specific terms, Kar and Cartwright-Smith (2010) asserted that capital flight has led to a substantial reduction in tax payments made by multinational firms and has also contributed to commercial tax evasion of around 60 to 65 percent of all the capital outflows, in the form of profit, from Africa. Unfortunately, no one can establish accurately the amount lost due to capital flight due to the hidden nature with which capital flight is perpetrated. Still, it is roughly estimated to be to the tune of hundreds of billions of dollars. For instance, FitzGerald (2013) estimates of foregone tax revenue due to capital flight from developing countries and found that developing countries as a group were losing tax revenue in the order of \$200 billion per year, representing $2.5 \%$ of their total GDP; Murphy (2007) estimated that the lost tax revenue annually from capital flight is about US $\$ 255$ billion on a worldwide basis; The Global financial integrity (GFI, 2010) conducted an analysis of the tax revenue loss that developing countries suffer due to trade mispricing and found that during the period of 2002 through 2006, the average tax revenue loss to all developing countries was between $\$ 98$ billion and $\$ 106$ billion annually representing an average loss of about 4.4 percent of the entire developing worlds' total tax revenue; According to UNCTAD (2015), developing countries lose about $\$ 100$ billion annually in tax revenues due to inward investments being routed through offshore financial centers. These figures are reflections of the impact of capital flight on the overall economy and the scale, more than sufficient to finance economic development and provide basic social services. However, the worry about capital flight, therefore, centers on what it does to tax revenue. The magnitude of these problems motivated the present study.

Hence, the study seeks to ascertain the existence of a causal relationship between capital flight and tax revenue as well as to determine the impact of capital flight on tax revenue. In achieving this, the rest of the study is structured in four sections. Next to the background of the study is the second section, which contains the review of literatures-empirical and theoretical review. Section three explains the research methods; section four discusses data analysis and interpretation, while the last section contains conclusion, recommendation and areas of further research.

\section{Literature Review}

The literature is loaded with findings which demonstrate the staggering effects of capital flight on the economies of developing country like Nigeria. Just like other African nations, Nigeria, rather than drawing in capital, she is losing it. These discoveries set up the effects of capital flight on the different divisions of an economy and all point to a similar heading that capital is lost to the economy experiencing capital flight. The utilizations to which capital flight are sent are many (Cardoso \& Dornbush, 1989); while a few examinations were essentially done on capital flight with no connection to some other economic variable and different investigations on capital flight with connection to an economic variable, for example, GDP, Household Venture (Ajayi, 1997; Agu, 2010; Ajilore, 2010). Strikingly, few investigations have been completed to decide its suggestions on tax income. This investigation ought to, in this way, be viewed as an imperative endeavor to fill these gaps identified in the empirical literature.

The investigation of Uguru (2016) on the ramifications of capital flight on tax income in Nigeria, by utilizing ordinary least squares (OLS) approach and measuring capital flight under Hot cash strategy. It was found that a partial increment in capital flight prompts two percent decline in tax income in Nigeria. Ndikumana and Boyce (2012) additionally have demonstrated that nations with higher capital flight will generally have lower taxable incomes. Taking an instance of capital flight on tax income and the real sector, Uguru (2011) utilizing the ordinary least square, assesses the job of capital flight on the execution records of benefit, cost of creation and expense paid by some chosen worldwide partnerships in Nigeria and found that corporate benefits which are expected to be reinvested into the economy are moved abroad. Also, the investigation further expresses that the nearness of 
exchange mispricing and over-invoicing of import increase the production costs of firms, which prompts an increase in the prices of products in Nigeria, and capital flight decreases government income through tax evasion.

In looking at capital flight from the more extensive point of view, (Obidike, Uma, Odionye, \& Ogwuru, 2015) explored the impacts of capital flights on the economic development in Nigeria. They used Autoregressive Appropriated Slacked model (ARDL), and the discoveries show that capital flight negatively affected economic improvement. The investigation of Collier, Hoeffler and Pattillo (2001) has a comprehensive methodology by considering the effect of capital flight on financial development in Nigeria utilizing time arrangement information from 1980 to 2012. The investigation assesses capital flight, against external reserves, debt, foreign direct investment, and current record offset co-integrated with total national output (Gross domestic product) in Nigeria. It accordingly found that the ascent of capital flight negatively affected the monetary development of the country.

Additionally, Oke and Kolapo (2010) utilized the ordinary least square (OLS) to analyze the impact of the determinants of capital flight on the Nigerian economic growth amidst 1985 and 2010. Total national output (Gross domestic product) was utilized as the development pointer. In contrast, foreign direct investment, inflation rate, conversion standard and monetary deficiency were utilized as the determinants of capital flight. The investigation observed foreign direct investment to be the major cause for capital flight in the short-run while both inflation and trade rates fundamentally decide capital flight over the long haul, which thus antagonistically impacts economic growth. Utilizing a two phases least-square strategy for the period 1970-2008, Saheed and Ayodeji (2012) analyze the impact of capital flight on the Nigerian economy and found that capital flight adversely and essentially impacts on financial development and that non-execution of residential assets can trigger capital flight. Olugbenga and Alamu (2013) inspected the effects of capital flight on Nigeria economic growth over a time of 30 years (1981 2010). The Johansen Co-coordination test was used to explore the dynamic connection between capital flight and economic growth. The outcome demonstrates that capital flight has a negative effect on economic growth in the short-run and otherwise over the long time period.

Onoja (2015) analyzed the dynamic impact of capital flight on genuine conversion scale of the naira, utilizing quarterly time series data covering 1981-2009 period. In particular, the investigation discoveries demonstrate that capital flight had a significant impact on genuine conversion scale, even at 10 percent probability level. Conversely, the investigation of Saheed and Ayodeji (2012) limited its very own degree by utilizing the ordinary least square (OLS) on auxiliary information gotten from National Bank of Nigeria (CBN), and National Bureau of Statistics (NBS). The examination insists that capital flight impacted the conversion scale in Nigeria over the period considered. The investigation built up that capital flight has no association with the genuine conversion scale of a country. Ajilore and Taiwo (2010) did an experimental investigation on the effect of capital trip on domestic investment. Utilizing the ordinary least square strategy, the examination found a negative yet insignificant effect of capital trip on domestic investment.

\subsection{Capital Flight: Studies Outside Nigeria}

Ndiaye and Siri (2016) considered the drivers of capital flight from Burkina Faso and its effect on tax income. Utilizing an econometric investigation, they revealed that a decrease in tax income and the Gross domestic product development rate, changes in monetary arrangement routines, and expansion in characteristic asset rents, external debt, and political viciousness prompt significant capital flight. The outcomes demonstrate a negative effect of capital flight on tax income. Beja (2007), in his investigation of capital flight and monetary execution of the Philippines, noticed that capital flight irritates assets limitations and along these lines debilitate long haul financial development. Maski and Wahyudi (2012) utilized the regression model to examine the impact of Gross domestic product development, foreign direct investment, exchange rate, and inflation on the presence of capital flight and found that even though the monetary development in Indonesia moves towards positive development rate and very high, the issue of abnormal state of capital flight out of the nation has a negative impact on the development possibilities. Furthermore, the investigation likewise discovered that just foreign direct investment has an impact on capital flight, while other factors had no impact.

Utilizing Cameroon and some developing nations, Beja (2006) individually saw that capital flight negatively impact monetary development. Also, Cardoso and Dornbusch (1996) examine utilizing a little board of change economies presents proof that high expansion, extensive spending deficiencies, quick swapping scale deterioration, and low genuine loan costs are altogether connected with expanded capital flight. Utilizing Kenya as a contextual investigation, DevKar and Cartwright-Smith (2008) directed an examination for the entire scope of developing nations and nations experiencing significant change from 2002 through 2006, evaluating capital flight utilizing the Hot Cash, the World Bank and exchange mispricing measures. The general discoveries of the examination show that 
unlawful monetary streams are developing in volume on a yearly basis with the biggest recorded surges originating from Asia and Europe while the Center East and North Africa continent exhibit the quickest yearly development.

\subsection{The Tax-Depressing Theory}

The tax depressing theory hypothesize capital flight prompts potential loss of tax income since money held abroad are outside the control of the host government and can't consequently be taxed or use for residential financial development and advancement. The fall in government income confounded the errand of the politico-monetary building to advance development and improvement. The ramification of this is the decrease in debt-adjusting limit of the administration, which thus expands the obligation trouble. Capital flight consequently disappoints residential asset preparation, and the immediate results of capital flight is the decrease in income creating capability of government.

\section{Data and Methodology}

This study adopted the pooled OLS research design (Adegboyegun et al., 2020a; Ademola et al., 2020b). Data were collected annually across the sample period (1980-2015) model from the Central Bank of Nigeria (CBN) statistical bulletin, Federal Inland Revenue Services and the National Bureau of Statistics (Lawal et al., 2016; Eluyela et al., 2018a, 2018b; Asaleye, Adama \& Ogunjobi, 2018; Oladipo et al., 2019a, 2019b). The outputs of the OLS regression is subjected to statistical tests which include $\mathrm{R}^{2}$, $\mathrm{t}$-test, and F-test to determine the significance of each independent variable stated in the model (Adegboyegun et al., 2020b; Nwanji et al., 2020). Other tests used include the Unit Root test, Co-integration and Error Correction Model (Asaleye et al., 2019; Lawal et al., 2018; Eluyela et al., 2019a, 2019b). A model is therefore built to capture the objectives of the study at a glance, and it is a reflection of the model already used by (Eluyela et al., 2019c; Uguru, 2016).

Hence the study adapted and modified the model used by Uguru (2016) in which tax revenue is expressed as a function of capital flight. However, the model was modified to include other relevant variables such as real gross domestic product, a measure of economic growth, and inflation rate in Nigeria as used and specified in the works of Ndiaye (2009) and Menbere, (2003) who examined the implications of capital flight for domestic investment and economic growth. Official statistics on Capital flight do not exist because these outflows escape the detection of regulatory agencies. Since a country's official statistics do not directly record the outflows of illicit capital, researchers have developed several proxy measures to study the phenomena (Dev Kar \& Devon, 2006; Ozordi, 2019).

However, there are different measures of capital flight. They include the Residual (or broad) method; Morgan Guaranty; Dooley method; Hot money method and the Trade mis-invoicing method (Oke \& Kolapo, 2012). However, the residual method is adopted in this study due to the popularity and wide acceptability of the methods among scholars - it has been used over time and in different capital flight-related works; it has been used in related studies which affected Nigeria and due to the availability of data for its elements (De Boyrie, 2010; Ndiaye, 2009; Gusarova, 2009; Popoola et al., 2018; Otekunrin et al., 2018; Ozordi et al., 2020). The period was selected based on the availability of data (See Ademola et al., 2020a; Umukoro et al., 2020)

The residual method takes capital flight as a residual of four balance-of-payments components: the increase in debt owed to foreign residents, the net inflow of foreign direct investment, the amount of the current-account deficit and the increase in foreign-exchange reserves. Thus, capital flight is computed as:

$$
C P F=\triangle E X T+F D I-(C A+\triangle R E S)
$$

Where CPF is the capital flight; $\triangle \mathrm{EXT}$ is the change in the external debt (adjusted for cross-currency exchange rate fluctuations); FDI is net foreign direct investment, CA is current account deficit, and $\triangle \mathrm{RES}$ is the net additions to the stock of foreign reserves.

The premise is that the two sources (inflows) finance the two uses (outflows) so that any inability of the two "sources of funds" to finance the two "uses of funds" is indicative of capital flight; that is, if the capital source is larger than the capital uses, then capital flight occurred due to the fact that any inflow that does not finance the current account deficit or add to reserves flees the country in the form of capital flight. One of the first measures of the residual method of capital flight was first used in "World Development Report" by the World Bank in 1985 (WDR85). The method attempts to measure the buildup of net foreign claims by the private sector without trying to distinguish between speculative or non-speculative flows or between "normal" and "abnormal" flows (Collier, Hoeffler, \& Pattillo, 2001; Okere et al., 2019).

A further step used in the calculation of the estimates of capital flight is allowing for the mis-invoicing of both exports and imports; Trade Mispricing model since the largest means of shifting capital out of Nigeria is reckoned to be 
transfer mispricing (Murphy, 2005). This trade-mispricing from both exports and imports are calculated and added together. The results are then added on to previous estimates of capital flight to generate new sets of estimates. Thus, we have equ (2):

$$
C P F=\triangle E X T+F D I-(C A+\triangle R E S)+M I S I N V
$$

Where MISINV is net trade mis-invoicing.

This generates illegal funds that are shifted abroad. To estimate the trade mis-invoicing, a developing country's exports to the world are compared to what the world reports as having imported from that country and also a country's imports from the world are compared to what the world reports as having exported to that country. Any discrepancies in partner-country trade data, after adjusting for the cost of freight and insurance implies over-invoicing of imports and under-invoicing of exports, indicating capital flight. Trade mis-invoicing is calculated as follows:

$$
\begin{aligned}
& \text { Xmis }=\text { Xct }- \text { Mwrld / } a x \\
& \text { Mmis }=\text { Xct }- \text { Mwrld / ax }
\end{aligned}
$$

Where Xmis and Mmis stand for export and import mis-invoicing respectively; Xct represents exports as reported by the country; Mwrld imports from the country as reported by the world; Mct indicates the imports reported by the country; Xwrld exports sent to the country as reported by the world's imports from that country and ax is the cost of freight and insurance.

Hence the model for the study is presented below in equ (3)

$$
T X R=f(C P F, R G D P, I N F)
$$

Assuming a linear relationship between our dependent variable and the independent variables, the statistical equation of the above function is written, as shown in equ (4):

$$
T X R_{t}=\alpha_{0}+\alpha_{1} C P F_{t}+\alpha_{2} R G D P_{t}+\alpha_{3} I N F_{t}+\delta_{t}
$$

Where: $\alpha_{0}, \alpha_{1}<0, \alpha_{2}>0, \alpha_{3}<0$

And:

TXR $=$ Total tax Revenue in Nigeria.

RGDP $=$ Real Gross Domestic Product of Nigeria

$\mathrm{INF}=$ Inflation Rate in Nigeria

\begin{tabular}{|c|c|c|c|c|c|c|c|}
\hline \multirow[t]{2}{*}{ VAR } & \multirow{2}{*}{$\begin{array}{l}\text { ADF TEST } \\
\text { AT LEVEL }\end{array}$} & \multirow{2}{*}{$\begin{array}{l}\text { ADF TEST } \\
\text { AT } \\
\text { FIRST } \\
\end{array}$} & \multirow{2}{*}{$\begin{array}{l}\text { ADF TEST } \\
\text { AT SECOND } \\
\text { DIFF }\end{array}$} & \multicolumn{3}{|c|}{ MACKINNON CRITICAL VALUE } & \multirow{2}{*}{$\begin{array}{lr}\text { ORDER OF } \\
\text { INTEGRATION }\end{array}$} \\
\hline & & & & $1 \%$ & $5 \%$ & $10 \%$ & \\
\hline TXR & -3.19415 & -4.844456 & & -4.24364 & -3.54428 & -3.20469 & $\mathrm{I}(1)$ \\
\hline $\mathrm{CPF}$ & -2.15371 & -6.140820 & & -4.24364 & -3.54428 & -3.20469 & $\mathrm{I}(1)$ \\
\hline RGDP & 0.14391 & -1.763984 & -5.782076 & -4.24364 & -3.54428 & -3.20469 & $\mathrm{I}(2)$ \\
\hline INF & -3.48056 & -5.428906 & & -4.25287 & -3.54849 & -3.20709 & $\mathrm{I}(1)$ \\
\hline
\end{tabular}

Where: $\alpha_{0}, \alpha_{1}, \alpha_{2}$ and $\alpha_{3}$ are parameter estimates and $\delta$ is the error term. A positive sign is expected from the parameter of RGDP, while a negative sign is expected from the parameters of CPF and INF.

\section{Result and Discussion}

Table 1. Unit Root Test using ADF Test

Source: Author's Computation (2018) 
Table 1 shows the stationarity of the variables at different levels of differencing. It could be seen that TXR, CPF and INF attain their stationarity at the first difference. Therefore, these variables are integrated of order one. On the other hand, RGDP attains stationarity at the second difference. Hence it is integrated of order two.

Table 2. Johansen Co-Integration Test using long-run model

\begin{tabular}{|l|l|c|c|l|}
\hline \multicolumn{1}{|c|}{ Eigenvalue } & Trace Statistic & $\begin{array}{c}\mathbf{0 . 0 5} \\
\text { Critical } \\
\text { Value }\end{array}$ & \multicolumn{1}{|c|}{ Prob. ${ }^{* *}$} & \multicolumn{1}{|c|}{$\begin{array}{c}\text { Hypothesized No of CE } \\
\text { (s) }\end{array}$} \\
\hline 0.605489 & 61.85622 & 47.85613 & 0.0014 & None $^{*}$ \\
\hline 0.404008 & 30.23257 & 29.79707 & 0.0445 & At most ${ }^{*}$ \\
\hline 0.298419 & 12.63665 & 15.49471 & 0.1288 & At most 2 \\
\hline 0.017099 & 0.586407 & 3.841466 & 0.4438 & At most 3 \\
\hline
\end{tabular}

* means a hypothesis is rejected at 0.05 probability level

Source: Author's Computation (2018)

Table 2 demonstrates that there are two (2) co-integrating factors in the outcome. This infers the null hypothesis of no co-integration among the factors ought to be rejected at five (5) percent probability level. In this regard, the alternative hypothesis of co-integration in the model should be accepted. The suggestion is that there is a long term relationship among the factors - TXR, CPF, RGDP and INF.

Table 3. Error Correction Model (ECM)

\begin{tabular}{|l|c|c|c|c|c|}
\hline \multirow{2}{*}{$\begin{array}{c}\text { Variables } \\
\text { TXR(1) }\end{array}$} & \multicolumn{2}{c|}{ Coefficients } & \multirow{2}{*}{ Std Error } & t-Statistic & \multirow{2}{*}{ Probability } \\
\cline { 2 - 5 } & Parameters & Values & & & \\
\hline C & $\alpha_{0}$ & -3.769468 & 0.329565 & -11.43772 & 0.0000 \\
\hline CPF(1) & $\alpha_{1}$ & -0.0000002 & $1.94 \mathrm{E}-06$ & -1.072188 & 0.2935 \\
\hline RGDP(2) & $\alpha_{2}$ & 0.948443 & 0.051599 & 18.38092 & 0.0000 \\
\hline INF(1) & $\alpha_{3}$ & -0.004817 & 0.001991 & -2.419603 & 0.0228 \\
\hline ECM(-1) & $\alpha_{4}$ & 0.001028 & 0.002129 & 0.482682 & 0.6334 \\
\hline Rsquared & 0.967357 & & & & \\
\hline Adjusted Rsquared & 0.962335 & & & & \\
\hline F-statistic & 192.6241 & & & & \\
\hline Prob(F-statistic) & 0.000000 & & & & \\
\hline Durbin-Watson Stat & 1.271866 & & & & \\
\hline
\end{tabular}

Source: Author's Computation (2018)

Table 3 indicates that the lagged error correction term $\left(\mathrm{ECM}_{\mathrm{t}-1}\right)$ which shows the long-run relationship. The co-efficient of the error (0.001028) indicates that a long-run relationship does not exist, so there is no adjustment in the economy. If there should be disequilibrium in the economy, there will be no adjustment of 0.1 percent to the equilibrium in the short run neither by the market mechanism, government intervention, nor both.

\subsection{Regression Analysis}

Table 4 below shows that the co-efficient of the constant parameter is positively related with the TXR. This indicates that if all explanatory variables are held constant, TXR will increase by 241.0551units. The co-efficient of the CPF is -0.025987 , indicating a negative relationship exists between TXR and CPF expectation meaning that a unit increase in CPF will lead to -0.025987 decreases in TXR. The analysis of the study model reveals that a hundred per cent increase in the capital flight causes a 2.5 percent reduction in tax revenue in Nigeria and vice versa, provided all other variables such as RGDP and INF are held constant. Conversely, a hundred percent increase in the Real Gross 
Domestic Product of the nation leads to 0.004 percent increase in the tax revenue and vice versa, provided all other variables such as CPF and INF are held constant. Also, a unit increase in the inflation rate dampens the tax revenue by 5.01 percent and vice versa, provided all other variables such as CPF and RGDP are held constant.

Table 4. Regression Analysis

\begin{tabular}{|l|c|c|c|c|c|}
\hline \multirow{2}{*}{$\begin{array}{c}\text { Variables } \\
\text { TXR }\end{array}$} & \multicolumn{2}{c|}{ Coefficients } & Std Error & t-Statistic & Probability \\
\cline { 2 - 5 } & Parameters & Values & & & \\
\hline C & $\alpha_{0}$ & 241.0551 & 130.5302 & 1.846738 & 0.0741 \\
\hline CPF & $\alpha_{1}$ & -0.025987 & 0.005930 & -4.382647 & 0.0001 \\
\hline RGDP & $\alpha_{2}$ & 0.000044 & $6.56 \mathrm{E}-06$ & 6.728380 & 0.0000 \\
\hline INF & $\alpha_{3}$ & -5.014784 & 4.324714 & -1.159564 & 0.2548 \\
\hline Rsquared & 0.936061 & & & & \\
\hline Adjusted Rsquared & 0.930067 & & & & \\
\hline F-statistic & 156.1599 & & & & \\
\hline Prob(F-statistic) & 0.000000 & & & & \\
\hline Durbin-Watson Stat & 1.136731 & & & & \\
\hline
\end{tabular}

Source: Author's Computation (2018)

The R-squared and Adjusted $\mathbf{R}^{2}$ : The $\mathbf{R}^{2}$ indicates that the independent variables account for 93.6 per cent of the variation or changes in the output of the tax revenue of Nigeria. This captures the explanatory power of the model. The remaining 6.4 per cent is caused or explained by other factors not considered in the model of this study.

The t-statistic: The regression result reveals that CPF and RGDP are statistically significant, but INF is not significant. From the t-test, the t-statistic value of -4.382647 for CPF and 6.728380 for RGDP are more significant than 2 while -1.159564 for INF is less than 2 . Therefore, it is not significant. Hence these variables have a significant influence on the dependent variable.

F-statistic: The F-calculated (statistic) of 156.1599 measures the overall statistical influence of the explanatory variables in explaining the dependent variable with the corresponding probability value of 0.00000 shows that the model is well fitted and the explanatory variables are statistically significant because it is higher than the tabular value of $\mathrm{F}$ distribution (indicated by the adjusted $\mathrm{R}$ ). Therefore, the explanatory variables of Capital Flight, Real Gross Domestic Product and Inflation Rate are statistically significant.

\begin{tabular}{llll}
\cline { 3 - 4 } & & \multicolumn{2}{c}{ Decision } \\
\hline F -calculated & F -tabulated & $\mathbf{H}_{\mathbf{0}}$ & $\mathbf{H}_{\mathbf{1}}$ \\
\hline 99.68012 & 2.84 & Reject & accept \\
\hline
\end{tabular}

\section{Conclusion and Recommendations}

The direct economic impacts of capital flight from developing countries in general and Nigeria, in particular, cannot be precisely quantified. It is, however, empirically proven that not only are they negative, but also of significant consequence. In the final analysis, capital flight is a perennial scourge that must be curbed. As long as there is an influx of foreign direct investments in the country, capital flight is a possibility. Capital flight undermines tax revenue in the country and denies the country, the economic opportunities inherent in this illicit cash outflow. It may be difficult to eliminate capital flight from the system, but it can be controlled, and its economic impact reduced to a considerable extent.

This study, at this juncture, intends to make recommendations, based on the findings of this study. These recommendations can help in curtailing the practice of capital flight within the Nigerian economy and allow resources to be channelled to productive activities in the country. 
First and foremost, the study revealed that capital flight had a negative impact on tax revenue. In the light of this, it is suggested that Federal Inland Revenue System, the department saddled with the responsibility of tax collection, should review the tax system and policies with the sole aim of plugging loopholes in the existing tax system thereby preventing organizations from evading and avoiding taxes. Interestingly, the Federal Inland Revenue Service (FIRS) seems to have woken up to this realization as captured in This Day daily publication of 3rd of March 2017, where it was reported that the West African Union of Tax Institutes' (WAUTI) met to brainstorm and propose recommendation on how to boost domestic resource mobilization and check revenue leakages, in the face of a global fall in commodity prices and almost non-existent donor support. With the loopholes fixed, a mechanism can be designed to monitor the illicit movements of financial resources from indigenous and multinational firms in the country to other countries and equally play the role of a "whistleblower" that alerts the authority about illicit activities of foreign and indigenous firms in Nigeria. With this, the mechanism will serve as a deterrent to illicit activities of foreign and indigenous firms. These flights of capital will only lessen if the reputational and financial risks increase due to whistle-blowers, tax leaks and improved international cooperation on tax matters. Also, the development of robust monitoring and frequent audit framework focused on the activities of the Multi-National Companies (MNCs) will go a long way in preventing capital flight.

Furthermore, the government should review its trade and investment policy and insert stiff penalties into it to punish companies that perpetrate capital flight and deter the possibility of perpetuating it in the future. There is nothing more deterring to the crime of capital flight than the knowledge of being fined heavily should the crime be discovered. The act of imposing heavy fines on erring organizations is a norm in many advanced countries, and it is a huge source of extra revenue for those governments. Hence the government or tax authority in the country can borrow a leaf from this approach. In the same vein, the study shows that economic growth, measured by the real gross domestic product, enhanced the performance of tax revenue. It is therefore suggested that the government should stimulate the economic growth of the country by focusing on continual capital projects' investment and implementation, its monitoring and fixing, in addition to regulation, frequent checks and balances while making the business environment conducive for economic activities. Increase in economic activities will inadvertently increase tax revenues generated for the government.

Lastly, the study outcome shows that inflation rate undermined tax revenue in Nigeria. In other words, the inflation rate raises the general price level and thereby reduces the purchasing power of the consumers. In return, the aggregate level of demands falls and forces firms in the real sector to reduce productive activities. A reduction in productive activities automatically reduces the tax revenues government derives from these firms. It is therefore suggested that appropriate monetary and fiscal policies should be adopted to curb the persistent rise in the general price level. The findings support that of Uguru (2016), Ndiaye \& Siri (2016) and also the tax- depressing theory of capital flight.

\subsection{Suggestions for Further Studies}

In this study, the impact of capital flight on tax revenue in Nigeria between 1980 and 2015 was considered. This study did not delve into critical research about the determinants or elements of capital flight in Nigeria. There are components or determinants of capital flight, researching into these determinants of capital flight may give insights into how best to curb the menace of capital flight in Nigeria and all developing countries at large. Hence this study will be better appreciated if it is complemented by another independent study on the components of capital flight.

\section{Acknowledgment}

The authors wish to appreciate the management of Landmark University for payment of the article processing fee (APC).

\section{References}

Adegboyegun, A. E., Alade, M. E., Ben-Caleb, E., Ademola, A. O., Eluyela, D. F., \& Oladipo, O. A. (2020b). Integrated reporting and corporate performance in Nigeria: evidence from the banking industry. Cogent Business and Management, 7(1), https://doi.org/10.1080/23311975.2020.1736866

Adegboyegun, A. E., Ben-Caleb, E., Ademola, A. O., Madugba, J. U., \& Eluyela, D. F. (2020a). Fair value accounting and corporate reporting in Nigeria: a logistics regression approach. International Journal of Financial Research, 11(2), 301-310. https://doi.org/10.5430/ijfr.v11n2p301

Ademola, A. O., Ben-Caleb, E., Adegboyegun, A. E., Eluyela, D. F., Falaye, A. J., \& Ajayi, A. S. (2020b). Rotating and savings credit association (ROSCAs): A veritable tool for enhancing the performance of micro and small 
enterprises in Nigeria. Asian Economic and Financial Review, 10(2), 189-199. https://doi.org/10.18488/journal.aefr.2020.102.189.199

Ademola, A. O., Ben-Caleb, E., Madugba, J. U., Adegboyegun, A. E., \& Eluyela, D. F. (2020a). International public sector accounting standards (IPSAS) adoption and implementation in Nigerian public sector. International Journal of Financial Research, 11(1), 434-446. https://doi.org/10.5430/ijfr.v11n1p434

Agu, C. (2010). Domestic macroeconomic policies and capital flight from Nigeria: Evidence from a macro-econometric model. CBN Economic and Financial Review, 48(3), 4-13.

Ajadi, S. F. (2008). Econometric analysis of capital flight in developing countries: a study of Nigeria. 8th Global Conference on Business \& Economics. (October 18-19 ${ }^{\text {th }}$ ) 2008, Florence, Italy.

Ajayi, S. I. (1997). An analysis of external debt and capital flight in the severely indebted low-income countries in Sub- Saharan African. Washington, DC: IMF.

Ajilore, O., \& Taiwo, K. (2010). An economic analysis of capital flight from Nigeria, International Journal of Economics and Finance, 2(4), 10-19.

Asaleye, A. J., Adama, J. I., \& Ogunjobi, J. O. (2018). Financial sector and manufacturing sector performance: evidence from Nigeria. Investment management and innovations, 15(3), 35-48. https://doi.org/10.21511/imfi.15(3).2018.03

Asaleye, A. J., Lawal, A. I., Popoola, O., Alege, P. O., \& Oyetade, O. O. (2019). Financial integration, employment and wages nexus: evidence from Nigeria. Montenegrin Journal of Economics, 15(1), 141-154. https://doi.org/10.14254/1800-5845/2019.15-1.11

Beja, Jr. (2006). Capital flight and economic performance: growth projection for Philippines. Munich Personal Archive, Paper. 4885.

Boyce, J., \& Ndikumana, L. (2012). New estimates of capital flight from sub-Saharan African Countries: Linkages with External Borrowing and Policy Options. Mimeo, University of Massachusetts.

Cardoso, E., \& Dornbusch, R. (1996). Foreign private capital flows. Handbook of Development Economics, Vol. II, Amsterdam, North Holland.

Collier, P., Hoeffler, A., \& Pattillo, C. (2001). Flight capital as a portfolio choice. World Bank Economic Review, 15, 55-80.

De Boyrie, M. E. (2010). Determinants of capital flight and capital movement through trade mispricing: The African case. African Journal of Accounting, Economics, Finance and Banking Research, 6(6), 15-24.

Eluyela, D. F., Adetula, D. T., Obasaju, O. B., Ozordi, E., Akintimehin, O., \& Popoola, O. (2019a). Foreign directors, indigenous directors and dividend payout structure in Nigerian deposit money banks. Banks and Bank System, 14(2), 1-14. https://doi.org/10.21511/bbs.14(2).2019.16

Eluyela, D. F., Adetula, D. T., Oladipo, O., Nwanji, T. I., Adegbola, O., Ajayi, A., \& Falaye, A. (2019b). Pre and post-adoption of IFRS based financial statement of listed small and medium scale enterprises in Nigeria. International Journal of Civil Engineering and Technology, 10(1), 1097-1108.

Eluyela, D. F., Akintimehin, O. O., Okere, W., Ozordi, E., Osuma, O. G., Ilogho, S. O., \& Oladipo, O. A. (2018a). Board meeting frequency and firm performance: examining the nexus in Nigerian deposit money banks. Heliyon, 4. https://doi.org/10.1016/j.heliyon.2018.e00850

Eluyela, D. F., Akintimehin, O. O., Okere, W., Ozordi, E., Osuma, G. O, Ilogho, S. O., \& Oladipo, O. A. (2018b). Datasets for board meeting frequency and financial performance of Nigerian deposit money banks. Data in Brief, 19, 1852-1855. https://doi.org/10.1016/j.dib.2018.06.044

Eluyela, D. F., Olajide, D., Tolase, O. A., Okere, W., Ogabi, M., \& Kafidipe, A. (2019c). Impact of gender dichotomy on dividend payout policy in listed Nigerian financial services firm. Cogent Business and Management, 6, 1-10. https://doi.org/10.1080/23311975.2019.1687270

FitzGerald, V. (2013). The international fiscal implication of global poverty reduction and global public goods provision. Unu Wider Working Paper No. 2013/136. Helsinki: Finland: Unu Wider.

Global Financial Integrity. (2010). The Implied Tax Revenue loss from Trade Mispricing: 2002-2006. Washington, DC: Global Financial Integrity. 
Isu, H. O. (2002). Capital flight and Nigeria's development: An analytical review. Journal of Finance, Banking and Investment, 2(2), 31-42.

Kapoor, S. (2007). International taskforce on illicit financial flows and capital flight. Briefing Paper for the First Meeting of the Taskforce. Ministry of Foreign Affairs, Norway.

Kar, D., \& Cartwright-Smith, D. (2010). Illicit financial flows from Africa: hidden resource for development. Washington, DC: Global Financial Integrity. Retrieved from http://www.gfintegrity.org/storage/gfip/documents/reports/gfi_africareport_web.pdf

Lawal, A. I., Babajide, A. A., Nwanji, T. I., \& Eluyela, D. (2018). Are oil prices mean reverting? Evidence from unit root tests with sharp and smooth breaks. International Journal of Energy Economics and Policy, 8(6), 292-298. https://doi.org/10.32479/ijeep.6980

Lawal, A. I., Nwanji, T. I., Asaleye, A., \& Ahmed, V. (2016). Economic growth, financial development and trade openness in Nigeria: An application of the ARDL bound testing approach. Cogent Economics and Finance, 4(1), 1-15. http://doi.org/10.1080/23322039.2016.1258810

Lessard \& Williamson. (1987). Capital flight and third world debt. Journal of International Business Studies, 19(3), 67-77.

Libabatu, S. G. (2014). Tax revenue and economic growth in Nigeria (An Unpublished Thesis). Ahmadu Bello University, Zaria, Nigeria.

Maski, G., \& Wahyudi, S. T. (2012). A causality between capital flight and economic growth: A case study of Indonesia. Working Paper, Department of Economics, Brawijaya University, Indonesia.

Menbere, W. T. (2003). Absolute convergence across time and space: New empirical evidence for an old debate. Ekonomick'y 'casopis, 51(10), 1270-91.

Murphy, R. (2005). Fiscal Paradise or Tax on Development? Retrieved from www.File://A:I3worldfiles lboomerang.html

Ndiaye, A. S. (2009). Examining the effect of capital flight on domestic investment in the Franc Zone. Paper prepared for presentation at the African Econometric Society (AES) 14th Annual Conference on Econometric Modeling for Africa, Sheraton hotel, Abuja, Nigeria, 8-10 July 2009.

Ndiaye, A. S., \& Siri, A. (2016). Capital flight from Burkina Faso: drivers and impact on tax revenue. African Development Review, 28(1), 100-112. https://doi.org/10.1111/1467-8268.12184

Nwanji, T. I., Howell, K. E., Faye, S., Otekunrin, A. O., Eluyela, D. F., Lawal, A. I., \& Eze, S. C. (2020). Impact of foreign direct investment on the financial performance of listed deposit banks in Nigeria. International Journal of Financial Research, 11(2), 323-347. https://doi.org/10.5430/ijfr.v11n2p323

Obidike, P. C., Uma, K. E., Odionye, J. C., \& Ogwuru, H. O. (2015). The impact of capital flight on economic development: Nigeria in Focus. British Journal of Economics, Management and Trade, 10(3), 1-13.

Oke, M. O., \& Kolapo, F. T. (2012). Nigeria economic growth and capital flight Determinants. Asian Journal of Business and Management Sciences, 1(11), 76-84.

Okere, W., Eluyela, D. F., Lawal, A. I., Ibidunni, O., Eseyin, O., Popoola, O., \& Awe, T. (2019). Foreign expatriates on board and financial performance: a study of listed deposit money banks in Nigeria. The Journal of Social Science Research, 5(2), 418-423. https://doi.org/10.32861/jssr.52.418.423

Oladipo, O. A., Iyoha, O. F., Fakile, A. S., Asaleye, A. J., \& Eluyela, D. F. (2019a). Do government taxes have implication on manufacturing sector? Evidence from Nigeria. Journal of Management Information and Decision Sciences, 22(3), 181-190.

Oladipo, O. A., Iyoha, O. F., Fakile, A. S., Asaleye, A. J., \& Eluyela, D. F. (2019b). Tax revenue and agricultural performance: evidence from Nigeria. Problems and Perspectives in Management, 17(3), 342-349. https://doi.org/10.21511/ppm.17(3).2019.27

Olugbenga, A. A., \& Alamu, O. A. (2013). Does capital flight have a force to bear on Nigerian economic growth? International Journal of Developing Societies, 2(1), 15-22.

Onoja, J. E. (2015). A dynamic analysis of the impact of capital flight on real exchange rate in Nigeria. European Journal of Economics and Finance, 2(4), 15-19. 
Onwioduokit, E. A. (2007). Capital flight from Nigeria: An empirical re-examination. West African Monetary Institute Accra, Ghana.

Otekunrin, A.O., Nwanji, T.I., Agba, D.Z., Olowookere, J.K., Fakile, S.A., Ajayi, S.A., Falaye, A.J., Eluyela, D.F., Oladiran, T. (2018). Outsourcing of accounting services and strategic cost management method: (A Case Study of Dangote flour Plc and Doyin investment Nig. Ltd). In Proceedings of the 32rd International Business Information Management Association Conference, Seville, Spain.

Ozordi, E., Adetula, D. T., Eluyela, D. F., Aina, A., \& Ogabi, M. A. (2019). Corporate dynamism and cash holding decision in listed Manufacturing Firms in Nigeria. Problems and Perspectives in Management, 17(4), 1-12, https://doi.org/10.21511/ppm.17(4).2019.01

Ozordi, E., Eluyela, D. F., Uwuigbe, U., Uwuigbe, O. R., \& Nwaze, C. E. (2020). Gender diversity and sustainability responsiveness: evidence from Nigerian fixed money deposit banks. Problems and Perspectives in Management, 18(1), 119-129. https://doi.org/10.21511/ppm.18(1).2020.11

Pastor, M. (1990). Capital flight from Latin America. World Development, 18(1), 1-18.

Popoola, O., Asaleye, A. J., \& Eluyela, D. F. (2018). Domestic revenue mobilization and agricultural productivity: evidence from Nigeria. Journal of Advanced Research in Law and Economics, 4(34), 1439-1450. https://doi.org/10.14505/jarle.v9.4(34).31

Saheed, S., \& Ayodeji, S. (2012). Impact of capital flight on exchange rate and economic growth. International Journal of Humanities and Social Science, 2(13), 247-255.

Uguru, L. C. (2016). On The Tax Implications of Capital Flight: Evidence from Nigeria. Journal of Research in Economics and International Finance, 5(1), 1-7.

Uguru, L. C., Ozor, B. M., \& Nkwagu, C. C. (2014). Capital flight and exchange rate volatility in Nigeria: The Nexus. Research Journal of Finance and Accounting, 5(16), 13-21.

Ugwuanyi, U., \& Uguru, L. C. (2010). Foreign direct investment and capital flight from Nigeria: An Empirical Analysis. Journal of Media, 2(1), 151-161.

Umukoro, O. E., Eluyela, D. F., Ozordi, E., Inua, O. I., \& Balogun, S. B. (2020). Nollywood accounting and financial performance: evidence from Nigerian Cinemas. International Journal of Financial Research, 11(2), 271-280. https://doi.org/10.5430/ijfr.v11n2p271

\section{Copyrights}

Copyright for this article is retained by the author(s), with first publication rights granted to the journal.

This is an open-access article distributed under the terms and conditions of the Creative Commons Attribution license (http://creativecommons.org/licenses/by/4.0/). 